\title{
PROBING THE FEASIBILITY OF THE INDIGENISATION OF NIGERIAN MEDIA IN AN ERA OF CULTURAL GLOBALISATION: A STUDY OF NIGERIAN RADIO AND TV PRODUCERS
}

\author{
Floribert Patrick C. ENDONG*
}

\begin{abstract}
The myth of media imperialism (presumably engendered by the globalisation current) has motivated most less developed countries to adopt customised media policies geared towards cultural protectionism. In line with this protectionist movement, Nigeria has adopted a local content policy which, over the years, has militated for a national media output which is dominantly shaped according to its local cultural specificities. This policy which strongly urges endogenous broadcasters to thrive to attain a 100 percent local content has variously been assessed by media practitioners and ideologues. Using secondary sources and critical observations, this paper argues that, although laudable, the idea of resorting to local content regulation for cultural protection in the Nigerian media sphere has been poorly conceived. Government has so far failed to provide all the accompanying measures to secure the success of this policy. As conceived by Nigeria, the policy does not provide a comprehensive and clear cut definition of local program and Nigerianess. Also, the policy's insistence on a 70-100 percent is utopian. It really overlooks the fact that Nigerian audiences have progressively become Westernised and logic will want media producers to pragmatically go for western or westernised media programs, so as to stay afloat.
\end{abstract}

Keywords: Cultural Protectionism, Cultural Globalisation, Local Content Regulation, Media Indigenisation, Media Imperialism, Westernization.

* Makale Türü: Araştırma Makalesi Paper Type: Research Paper

Geliş tarihi/Received: 06.08.2010 Kabul tarihi/Accepted:14.06.2021

DOI: https://doi.org/10.18221/bujss.777426

* PhD, University of Calabar, Department of Theatre, Film and Carnival Studies, floribertendong@yahoo. com, ORCID: 0000-0003-1893-3653 


\title{
KÜLTÜREL KÜRESELLEŞME ÇAĞINDA NIJERYA MEDYASININ YERLILEŞTiRILIMESININ UYGULANABILLIRLIĞiNIN IRDELENMESI: NIJERYALI RADYO VE TV YAPIMCILARI ÜZERINE BİR ÇALIŞMA
}

\author{
Floribert Patrick C. ENDONG*
}

\section{ÖZ}

Medya emperyalizmi miti (muhtemelen küreselleşme akımının doğurduğu), en çok da az gelişmiş ülkeleri kültürel korumacılığa yönelik özelleştirilmiş medya politikaları benimsemeye teşvik etmiştir. Bu korumacı akım doğrultusunda Nijerya, yıllar içinde baskın olarak yerel kültürel özelliklerine göre şekillenen bir ulusal medya faaliyetini teşvik eden yerel bir içerik politikası benimsemiştir. Yerel yayıncıları yüzde 100 yerel içerik üretmeye şiddetli bir şekilde teşvik eden bu politika, medya çalışanları ve teorisyenler tarafından çeşitli şekillerde değerlendirildi. İkincil kaynaklar ve eleştirel gözlemler kullanan bu makale, övgüye değer olsa da, Nijerya medya alanında kültürel koruma için yerel içerik düzenlemelerine başvurma fikrinin yetersizce tasarlandığını savunmaktadır. Hükümet şimdiye kadar bu politikanın başarısını güvence altına almak için gerekli tüm önlemleri sağlamada başarısız olmuştur. Nijerya tarafından düşünüldüğü gibi, bu politika, yerel program ve Nijeryalılı̆̆ın kapsamlı ve net bir tanımını sunmamaktadır. Ayrıca bu politikanın yüzde 70-100 ısrarı ütopiktir. Bu politika Nijeryalı izleyicilerin giderek Batılılaştığı gerçeğini ve bu mantıkla medya üreticilerinin ayakta kalmak için pragmatik olarak batılı veya batılılaşmış medya programlarını tercih edeceğini gözardı etmektedir.

Anahtar Kelimeler: Kültürel Korumacılı, Kültürel Küreselleşme, Yerel İçerik Düzenlemesi, Medya Yerlileştirme, Medya Emperyalizmi, Batılılaşma. 


\section{INTRODUCTION}

Like most of her conservative African counterparts, Nigeria has adopted the indigenisation paradigm as a working tool to promote cultural preservation and mitigate western cultural imperialism in its media sector. In tandem with this, the country has promulgated a media policy (a broadcast code) which strongly urges nation-based broadcasters to thrive for a 70-100 percent local content, and which is theoretically designed to ensure that national media output be dominantly shaped according to local cultural specificities. As stipulated in Section 3(11.1) of the 6th edition of the Nigerian Broadcasting Code, Nigeria's local content policy has two essential targets:

a.promote and sustain Nigeria's diverse cultures, mores, folklores and community life; and

b.provide diversity in types of programming content for the widest audience through the limitless variety in the cultural landscape of Nigeria. (Nigerian Broadcasting Commission, 2016, sec. 3) If a considerable body of literature has sought to examine this media indigenisation policy in a bid to show its benefits and its implications in the realm of cultural heritage preservation, very little attention has been given to its feasibility, particularly in an era of cultural globalisation. Scholars such as Effiom (2005), Salawu (2004, 2006) and Obono and Madu (2010) have explicitly or tacitly assessed the extent to which Nigerian media houses adhere to the policy; while other scholars such as Endong $(2014,2015)$ and Omoera and Ibagere (2010) have explored some of the challenges faced by the policy in the Nigerian broadcast landscape. The researchers who have accorded their attention to such challenges have mostly hinged on external critics' (non-media entities') point of view or personal observations. Virtually no endogenous scholar has endeavoured to examine the question (of the application of indigenisation in Nigerian broadcast media) from the angle of producers, program managers and presenters who are charged with the responsibility of implementing this policy in various Nigerian broadcast media. Also, the multifaceted effects of (cultural) globalisation on the application of the indigenisation policy in Nigerian media have virtually remained unexplored or at least understudied by both exocentric and indigenous scholars.

In view of this scenario, a number of questions pertaining to the reception of the indigenisation policy in Nigerian broadcast media houses still beg for attention. Some of these questions include the following: how well has the indigenisation policy been implemented in the Nigerian media landscape, in the last five years? How have producers, program managers and presenters perceived this policy? What specific problems do they personally encounter in the implementation of this policy? How have issues such as the westernisation of producers and audiences influenced the implementation of the indigenisation policy in the Nigerian media?
Based on secondary sources and critical observations, this paper sets out to answer the above mentioned questions. The paper is structured into three main sections. The first section provides a conceptual framework giving attention to indigenisation of media broadcast and cultural globalisation. The second section deals with the question of the feasibility of media indigenisation in an era of globalisation while the last section critically examines the indigenisation policy in Nigeria, from the prism of Nigerian TV and radio producers, presenters and other media practitioners.

\section{CONCEPTUAL AND THEORETICAL ISSUES}

To ensure the clarity of our analyses in the subsequent parts of this discourse, it will be expedient, from the outset, to provide definitional illuminations on two key concepts featuring in the topic under discourse; these concepts are indigenisation and cultural globalisation. The two concepts are most often used according to contexts. Therefore, this section seeks to specifically highlight aspects of these concepts/ variables that will be considered in the paper.

\subsection{Indigenisation}

The term indigenisation is highly polysemic as its meaning varies according to contexts. In anthropology, it is used to describe a process whereby the locals imbibe values from the outside world and make them (these imported values) theirs. In this context, indigenisation has an inextricable link with, or could even be regarded as the domestication or naturalisation of exocentric (cultural) values.

Such forms of domestication and naturalisation are illustrated by movements such as "Africanisation" and "Europeanisation". In the world of politics however, indigenisation is defined as a process whereby nations redefine their native land for better, "purging" themselves from exocentric concepts which they hitherto adhered to. In this context, indigenisation is viewed as another way of resisting foreign cultural imperialism. This is illustrated by movements such as re-Islamisation (in Muslim nations), Hinduisation (in India), Asianisation and the "Nihonjiron" in Japan among others. The Nihinjiron is otherwise called the theory of Japan and Japanese.

In economics, the definitions given to the term indigenisation somehow conflict with the above mentioned conceptualisations. In effect, the term is often construed as a policy consisting in augmenting local participation or ownership of a foreign-owned business or company. An extreme form of indigenisation, in this context, will be the nationalisation of foreign-owned companies. Without totally discarding the first two conceptualisations mentioned above, this paper defines indigenisation as a process consisting in adapting foreign concepts to local situations or industries. 
In line with this, indigenising media broadcast is to be understood as shaping media practices as well as media programming according to local specificities. This may imply increasing local contents in media production and considering local hands, local talents, expertise and local industries in the packaging of these media programs.

From many indications, it may be argued that the local contents policy - underscored in a media indigenisation scenario - is doubly rooted in the cultivation and cultural protectionism theories. In effect, the popular belief is that the media (particularly film and television) cultivate audiences' perception of reality. Going from this premise it may be argued that the cultural contents of foreign media broadcast may cultivate local people's perception of reality as well as their attitude, obviously in favour of imported cultures. Thus, if local media houses' programming is predominantly western, there is a high probability that countries' local cultures may be lost or influenced by external factors. This possible regrettable scenario given justifies countries' adoption of various cultural protectionist policies - notably indigenisation of media programming or the local content quotas - to push local media productions and industries and indirectly participate in the preservation/promotion of endogenous cultures.

\subsection{Cultural Globalisation}

Cultural globalisation could be defined as the rapid movement of ideas, values, cultural products, meanings and attitudes across national boundaries. It is also the interaction of cultures around the world, facilitated by a wide range of factors some of which include migration, international tourism, the transnational marketing of particular brands, popular entertainment and more especially information and communication technologies such as the Internet and the World Wide Web among others. The concept of cultural globalisation partly stems from the idea that there is a common mono-culture which is now subtly spread in the whole world - what some critics have called a "global culture". Such global culture is equally re-enforced by a multiplicity of agents, chiefs among which are innovations in information and communication technologies and global mass media. Cultural globalisation is thus often construed to be opposed to cultural purism or distinctiveness which entails a scenario where people protect their cultural traditions to the extent that they remain clearly distinct from one another.

A critical look at literature available reveals that cultural globalisation has three principal theories, namely homogenisation or standardisation, polarisation and hybridisation

i. The homogenisation theory is rooted in the belief that the proliferation of such forces as Americanisation and Westernisation has made global cultures homogenous in various respects. The proponents of this theory often illustrate their arguments using the phenomenal spread of the "culture ideology of consumerism" in the world (that is the trans-nationalisation of such modern cultures as MacDonalds and Starbucks) which, they think, has orchestrated a subtle standardisation of tastes and desires in various parts of the world. Another argument used by the proponents of this theory is the fact that the Internet has enabled the homogenisation of English as the world's common language. In brief, the homogenisation/ standardisation postulate of cultural globalisation argues that globalisation has progressively and subtly threatened - if not destroyed - cultural diversity in the world, transforming the world into a pandemic of Western cultures (Samalavicius, 2005; Watson, 2016; Endong, 2017). On this basis, cultural globalisation is arguably regarded as a vector of Western cultural imperialism and a threat to any effort towards the authentic preservation of non-Western cultures. By extension, it may be argued that cultural globalisation is a serious threat to such policies as media indigenisation and local content.

ii. The polarisation postulate of globalisation, on the other hand, radically negates the homogenisation view, as it argues that the process of globalisation does not always engender a global culture or a resemblance between world cultures. Rather, it promotes the spread of all existing cultures, including less represented ones. In tandem with this, cultural globalisation is often viewed as a vector of multi-culturalism. This thesis sounds plausible if one considers the various ways in which the Internet has enabled the globalisation of other languages (including minority African and Asian languages). In effect, the Internet has provided an enabling environment for the creation of online encyclopaedias and other web-based tools in indigenous non-Western languages. Similarly to the Internet, the proliferation of Thai, Chinese, Indian and Mexican restaurants around the world has, these last decades, represented a counter force to MacDonaldisation (Survadinata 2011). The polarisation theory of globalisation is very much vivid in Huntington's (1993) concept of "clash of civilisation". According to this concept, the interconnection of cultures under the ambit of globalisation rather gives birth to a situation wherein cultures develop a civilisation consciousness that leads them to appreciate differences between them.

iii. The hybridisation theory argues that cultural globalisation creates a situation whereby world cultures progressively take synergic forms by borrowing or integrating elements from sister cultures. This theory solidly rests on two things: first, the observable instances of culture mixing in various parts of the world; and second, the emergence of such cultural movements as glocalisation which strongly emphasise the creation of hybrid cultures - that is, cultures which simultaneously integrate both the local and the global and which, paradoxically, are not reducible exclusively to the local or the global. Given the fact that indigenisation often emphasises local contents against foreign contents - which it does not totally reject - many critics have viewed it (indigenisation) as being perfectly compatible with hybridisation (Watson, 2016). 


\section{MEDIA INDIGENISATION IN AN ERA OF CULTURAL GLOBALISATION: HOW FEASIBLE IS IT IN BLACK AFRICA?}

The indigenisation of media broadcast - in the form of the adoption of transmission quotas that favour local media production - has become a dominant paradigm all over the world. In effect, most countries have adopted media policies which seriously limit foreign contents, visibly in a bid to protect indigenous cultures and local media industries. These policies institute local transmission quotas which vary from one country to another and which mostly range from 51 to 80 percent, giving a visible pre-eminence to locally produced media contents. Only rare cases like Venezuela and Namibia have adopted local broadcasting quotas that go below 51 percent. The Namibian broadcasting policy in particular institutes a local content quota which is as low as 20 percent, perhaps in line with a pragmatism which very much considers the difficulty - nay futility - of upholding cultural protectionism or purism in an era of cultural and media globalisation. Such media policies which theoretically favour or tolerate high foreign contents in local media programming are relatively rare on the Black continent. This is so, as most African countries' local content quotas range from 50 to 80 percent, with countries like South Africa and Nigeria appearing as the biggest champions of this high local contents paradigm (Aliagan 2017, Thinus, 2016, Leonard, 2016; Nigerian Broadcasting Commission, 2016).

If the culture of promulgating local content quotas on the broadcast media has been lauded in various quarters, particularly in traditionalist and conservative ones, the application and suitability of such quotas particularly in an era governed by cultural globalisation and rapid globalisation of western media has fuelled various thorny debates in both academic and professional circles. It goes without saying that the pros of the local content paradigm are enormous, as they go beyond cultural preservation to include job creation in the media sector and a boom of local media industries, evidenced by the sure emergence of new stories, new genres and news voices to defend endogenous minorities and cultures. However, the local content paradigm has in many cases been found nonfeasible and non-pragmatic due to some factors which are directly or indirectly related to the rapid globalisation of western media and media production paradigms.

One of these factors lies in the fact that local media productions are generally exorbitant and hardly cost effective for endogenous media houses in poor or underdeveloped countries, notably in Black Africa and Asia. A series locally produced in Cameroon or South Africa, for instance, is sometimes ten times costlier than one imported from the US. This scenario has created conditions favourable for the tremendous importation of foreign/ Western media contents and the accidental westernisation of media programming in most African countries, making the local content policy adopted by most Black African countries prove inapplicable to the letter or simply a dead letter. With the aid of concrete illustrations, Van Der Puye (2008) corroborates the above position. He notes that, despite the cultural pride demonstrated by most African countries and their "poorly articulated" efforts to institute local contents in the management/regulation of local media, what makes broadcasting possible or viable in most parts of Africa remains local media houses' high dependence on low-cost American productions. He thus explains that:

[One] basic problem [facing TV broadcasting in Africa] has been the financial cost in building local television systems on an economically sound foundation. Often, this is only possible by importing low-cost American productions. Films and television programs produced in the industrialized countries (especially the United States) are offered at dumping prices if you compare the cost of local productions. In most cases, the commercial and non-commercial television stations and networks extensively use these inexpensive imports. In Ghana, for example, an hour of Ghana-produced, television program cost between US\$800 and $\$ 2,400$. By contrast, American-produced television is offered to African countries at a cost of \$130-150 per one half-hour. Along with the entertainment value, political and cultural attitudes and values are also being imported in what is known as cultural invasion, cultural levelling, cultural imperialism, or 'picture tube imperialism.' (Van der Puyer, 2008)

Another challenge - which appears closely related to the above mentioned factor - is the fact that local media productions in many sub-regions of the Black Continent are generally of low quality, compared to the ones generated in Western countries. In view of this, audiences most often prefer foreign contents to local ones, pushing local media houses to preferably go for foreign media contents in a bid to provide more attractive programming to their audiences and ensure both audiences' loyalty and advertising revenues. An immense body of research has clearly rationalised this observation (Salawu 2006; Endong, 2014; Ekpang, 2008). In many of his online articles Thinus (2016) has, for instance, underscored the fact that the most watched contents on popular South African TV stations such as SABC3 are international by definition. This has been so despite the fact that locally produced programs are placed on primetime. An audience survey carried out in April 2016 revealed that foreign soaps broadcast on South Africa's SABC3 such as The Bold and the Beautiful and Days of Our Lives are more watched than local soaps and TV shows such as Isidingo, High Rollers and Top Billing. This voracious and seemingly unquenchable appetite exhibited by endogenous audiences for international media contents is observable in many other parts of Africa.

The fact that Western media productions are more attractive to audiences has pushed local producers particularly in Black African countries to review their production methods and media philosophies in favour of Western programming paradigms. 
At various degrees, they have, in some sense, often westernised their productions in a bid to attract audiences who, by coincidence or cultural snobbism, dominantly appear to be westernised in terms of the kinds of gratifications they seek or expect from media productions. A good illustration of this observation is seen in the fact that popular American and European series such as ABC TV's Desperate Housewives and TV shows such as Big Brother UK and Idols have been copied by Black African producers. Though involving local human resources, local talents, endogenous fashion and decoration industries, the African versions of these foreign/Western media programs tend to sell foreign concepts and cultures. The storyline and production style used for the Nigerian version of Desperate Housewives, for instance, closely follow the original U.S. version. The double westernisation of African audiences and local media producers/productions has thus made it difficult, if not futile, to effectively implement the local content aphorism particularly in Black African countries.

It has been argued that the phenomenal westernisation of African audiences and media producers is, in great part, a consequence of cultural globalisation. In fact, cultural globalisation has enabled a rapid standardisation and homogenisation of both media production paradigm and audiences' taste and media expectations (Aliagan, 2017; Effiom, 2005; Grawhall, 2006).

\section{LOCAL CONTENT REGULATION IN NIGERIA}

In a bid to protect local industries and mitigate Western cultural and economic imperialism in its territory, Nigeria has adopted the indigenisation policy in various sectors of its economy. As an acclaimed but highly controversial policy, the indigenisation paradigm has been instituted in such key areas of Nigeria's economy as the petroleum, oil and gas, telecommunications, banking, education and media production among others. In the media sector in particular, the policy has been made clearly visible with the introduction of broadcast regulations which "audaciously" and "ambitiously" advocate a $100 \%$ local content quota (to be respected by all broadcasting media organisations operating on Nigerian soil) and which merely tolerate foreign contents. For more clarity or precision, it could be observed that the Nigerian broadcast policy, which advocated a $60 \%$ local content in 2010, today urges endogenous broadcasters to thrive for a $100 \%$ local content. Section 3(11.2) of the 6th edition of the Nigerian Broadcasting Code stricto sensus stipulates that:

A [Nigeria-based] broadcaster shall (a) promote Nigerian content and encourage the production and projection of Nigerian life within and outside its borders; strive to attain $100 \%$ local content; and (b) establish a dynamic, creative and economically vibrant Nigerian broadcast industry.

By advocating a 100 percent local content, the Nigerian broadcast regulation clearly marginalises foreign contents.
Section 3(14) of the Nigerian Broadcasting Code provides conditions under which foreign content may be tolerated in local media's programming. It stipulates that:

Foreign content is permissible provided it conveys intrinsic relevance to the education, information and entertainment of the Nigerian citizenry. A Broadcaster shall ensure that the selection of foreign programmes reflects the developmental needs of the Nigerian nation, and ensure respect for Nigerian cultural sensibilities. [...] A Broadcaster shall not relay foreign broadcasts LIVE on terrestrial platforms, except special religious or sports programmes or events of national interest. A Broadcaster shall adhere to the principle of reciprocity in programme exchange and the record of the details of the agreement and implementation domiciled with the Commission. (NBC, 2016, sec.3)

It is thus visible, from the above mentioned observations, that the Nigerian media regulation pushes the idea of a media environment and a national media broadcast which strongly facilitate the pursuit of the country's cultural vision. This vision consists in protecting and promoting local cultures and local media industries. As expressed by Section 3 (10) of the Code, "local content regulation is essentially to: (a) promote and sustain Nigeria's diverse cultures, mores, folklores and community life; [and] (b) provide diversity in types of programming content for the widest audience through the limitless variety in the cultural landscape of Nigeria".

It goes without saying that such a local content policy is laudable. However, its over-ambitious and elusive nature coupled with the homogenising effects of cultural globalisation has caused many media critics and practitioners to doubt its feasibility. This has been so, irrespective of the fact that a number of recent empirical studies and "unscientific" investigations suggest that the policy is relatively doing well. A 2010 study conducted by Obono and Madu, for instance, revealed that some elite Nigerian broadcasters, namely the Nigerian Television Authority(NTA), the AfricanIndependentTelevision(AIT) and Silverbird Television (STV) have so far struggled to attain local content percentages that are above 80 (Obono and Madu, 2012). To this empirical study, one may add the fact that the non-respect of the local content regulation has rarely - nay never - featured among the NBC's reproaches addressed to Nigerian broadcasters these last five years. One easily observes that most of NBC's reprimands aimed at Nigerian broadcasters these last decades have mainly focused on issues like hate speech, seditious language, unethical advertisements, hyping, unbalanced reporting, invasion of privacy, unverified claims and libel among other forms of yellow journalism. It is thus hard to find cases of violation of the local content regulation that have been sanctioned by the NBC in recent times (Aliagan, 2017). No empirical study in the literature available and none of NBC's recent waves of sanctions against Nigerian broadcasters actually report such a violation. 
One will therefore need more empirical investigation to be able to determine the extent to which Nigerian broadcasters respect local content principles in their model of programming. However, for the main time, observers such as Salawu (2006), Omoera and Ibagere (2010) and Endong (2014) continue to doubt Nigerian broadcasters' strict compliance with local content rules. Omoera and Ibagere particularly opine that NBC's introduction of the local content rules has in no way deterred Nigerian endogenous broadcasters' tendency of heavily depending on international contents. As they put it, "close to two decades after the establishment of the NBC, the Nigerian TV has not moved substantially away from the feature of programmes and news items whose origin and content is basically foreign" (Omoera and Ibagere, 2010).

Furthermore, the rareness of NBC's sanctions meted on Nigerian broadcasters for violation of the local content regulation does not automatically exonerate the Nigerian version of media indigenisation from its multiple irregularities. Indeed, the local content policy appears faulty from its designers' conception of the term "Nigeria content" and its failure to clearly define the concept of "Nigerianess" in its provisions bordering specifically on local content quota. These will be discussed indetail in the subsequent sections of this discourse.

\subsection{Questionable Conceptualisation of Local Content}

It must be underlined from the outset that the concept of local content has mostly been elusive and complex. Most countries have mainly viewed local programs as those produced by nationals, which involve local talents (that is national talents), are designed for nationals and which are in line with national interests (Koblowe and Madu, 2012; Batharjee and Mendel, 2001). In tandem with this, the Broadcasting Services (Australian Content) Standard (1999), for instance, defines local content as any form of programming which is produced under the creative control of nationals of the country. Going by this definition, the document construes "Australian content" as any media program produced under the following conditions:

a. the producer of the program is, or the producers of the program are, Australian...; and

b. either: (i) the director of the program is, or the directors of the program are, Australian; or (ii) the writer of the program is or the writers of the program are, Australian; and

c. at least $50 \%$ of the leading actors, including voice actors, or on-screen presenters appearing in the program are Australian; and

d. in the case of a drama program - at least $75 \%$ of the major supporting cast appearing in the program are Australians; and

e. [ ...] the program is produced and post-produced in Australia...; and

f. in the case of an animated program - the program satisfies at least 3 of the following requirements: (i) the production designer is Australian; (ii) the character designer is Australian; (iii) the supervising layout artist is Australian; (iv) the supervising storyboard artist is Australian; (v) the key background artist is Australian.

The Nigerian Broadcasting Code has visibly followed this bandwagon in its way of defining local contents. In effect, the Code construes local content as any media production which adheres to the following principles:

a. [it is] made by authors, producers and workers who are Nigerians or residing in Nigeria; or,

b. produced under the creative control of Nigerians; or c. the production is supervised and controlled by a producer established in Nigeria; or,

$\mathrm{d}$. the contribution in a co-production is not controlled by a producer based outside Nigeria; or

e. the production originating from any other country is made exclusively by Nigerians or in co-production with non-Nigerians established in that country.

From the definitional illuminations provided above, one clearly sees that the Nigerian Broadcasting Code basically focuses on the nationality of media producers and talents involved as well as on the country in which the production is done. Very little or no serious attention is given to indigenous languages as a key feature of indigenous program. Also, very little attention is given to the imperative of encouraging an original or purely Nigerian production style. These two major lacunas have engendered a situation wherein indigenous programs are marginalised or worse, local media producers and presenters struggle to package their productions glaringly according to Western production paradigms. A very clear - but often neglected evidence of this assumption is the fact that, more than often, Nigerian media presenters and journalists have struggled to use - or rather mimic - European and American accents during presentation of their programs, thereby sidelining Nigerian spoken English in a technical/subtle way. Such Westernised Nigerian journalists and media presenters have often "Americanised" the pronunciation of indigenous names, sometimes distorting them. In other cases, such local media producers have struggled to deliver their programs by mimicking their American or Western "idols". This scenario gives credence to the thesis stipulating that although some locally made programs may be Nigerian in terms of intended contents and talents involved in the production, the accent and production paradigms used in delivering them (the programs) qualify them as Western. Nigerian Television Authority (NTA) producer Henshaw decries this reality as he contends that:

There are numerous Nigeria-based radio and TV stations which are staffed with presenters who are fond of Americanizing the English language they use on air. While on air, such media personnel speak Americana or simply Americanized native names as if they were born in the West or as if they have not even grown up in this part of the world - that is Nigeria [...] 
They don't speak English language [with a Nigerian accent]. Though some of them have interesting contents [to offer] one is left to wander if their productions qualify as local content (Endong, 2014).

The way peoples of African descent pronounce words of the European languages as well as traditional African words is today arguably considered part of their identity (Bobda, 2000). This is in line with McWhorter's (2014) contention that "the way people talk expresses their identity". By implication, it is plausible to argue that, with no intent to be apologetic of mispronunciations of English words, the Nigerian way of pronouncing English constitutes part of Nigerianess. Therefore, reading the news or presenting a TV or radio program in Nigerian spoken English should arguably be viewed by Africans as a way of affirming their identity. It is probably in line with this understanding that well established global broadcasters such as the British Broadcasting Corporation(BBC), Aljazeera and even CNN tend to "tolerate" and integrate into their programming, news reports filed by African correspondents or staff-men in a type of English spoken with oriental or African accent. Programs such as BBC's Network Africa are good cases in point. Sharing corollaries, Steffensen (2012) opines that:

Language discrimination is recognised by the BBC as a problem in relation to its domestic audience and the Corporation actively attempts to become more inclusive and representative of British society by broadcasting nonstandard accents. On the other hand, when representing foreign, and especially post-colonial and non-Western languages and cultures, accent is used to define the boundary between the native English-speaking community and its outside. Accents are used to represent and translate the outside in stereotyping ways that tend towards racialisation and towards actors using generic "Southern African" and "East Asian" accents that bear little resemblance to the actual phonological profile of native speakers.

The lesson derivable from BBC's Network Africa in particular is that, even with a Nigerianised spoken English, good indigenous programs can be produced and Nigerianess can be advertised or promoted through the way the English language is used on air or in packaging TV or radio programs. Therefore, the Nigerian Broadcasting Commission should explore the linguistic dimension of local production.

A problem similar to the linguistic westernisation of socalled local productions is Nigerian producers' frequent adoption of Western styles of production, sometimes by adhering to cultural snobbism or social conformism. This can vividly be illustrated by the fact that much of the pop videos broadcast in TV musical programs on Nigerian celebrate various concepts that will mostly be identified as Western or at least exocentric. For instance, the pop videos of most Nigerian celebrities and superstars enact scenes very much similar to American artistes: singers, dancers and actors within these videos are most often dressed in a Western way and made to mimic gansta and AfroAmerican lifestyle or fashion. Going from this observation, one may pertinently argue that some of the musical programs authored by Nigerian producers and depicting Nigerians may not, by their content, be purely local. Many of them may, by default, be described as hybrid but with a dominant foreign (or Western) content. Former Managing Director of the Cross River Broadcasting Corporation (CRBC), Liwhu Betiang shares corollaries as he posits that:

The concept [of indigenization] is problematic. How do you define indigenisation? A programme may be local but with foreign form. It may be local with foreign content. It may equally be said to be local; but when you critically look at it, the idea driving its conception is not local, but emanates from elsewhere, for instance the famous reality show Big Brother Nigeria is clearly inspired by Big Brother UK [...] In such a situation of ambiguity, how do you define indigenisation? I strongly think that the concept is highly problematic. (Endong, 2015)

As noted by Betiang above and many other Nigerian media critics, there are still many blatant ambiguity and unvoiced issues in Nigeria's indigenisation policy and local content regulations. By failing to deal with this ambiguity and other silent issues, Nigeria's media local content policy - which is otherwise loaded with a fair philosophy - remains difficult to implement effectively. In the absence of a clear definition of its principles, the policy may simply be unfeasible.

\subsection{The Problematic $100 \%$ Local Content}

The fact that the Nigerian Broadcasting Code institutes a 100 percent local content could be lauded in the country's conservative quarters; however, it must be underscored that the quota appears unrealistic, nonpragmatic and thus highly problematic to many Nigerian media producers. Indeed, it is highly problematic in a media environment where vital issues such as homegrown media technologies, investment in innovative programs, specialized programming with indigenized character continue to be a myth rather than a reality. The policy is also more of an ideal in a Nigeria where competition with (foreign) international broadcasters has intensified over the years with the help of the Internet, satellite and cable transmission. The best the Nigerian Broadcasting Commission has done so far in support of its local content regulation has been to create a National Content Development Fund in a bid to facilitate local content creation in the country (Kawu, 2018). However, the fruits of this initiative is yet to be palpable in the country's broadcasting sectors since local program creation continues to be exorbitantly high for both government owned and private broadcaster. This has been one of the factors responsible for local media's continuous and heavy dependence on foreign media contents. 
One will therefore need more empirical investigation to be able to determine the extent to which Nigerian broadcasters respect local content principles in their model of programming. However, for the main time, observers such as Salawu (2006), Omoera and Ibagere (2010) and Endong (2014) continue to doubt Nigerian broadcasters' strict compliance with local content rules. Omoera and Ibagere particularly opine that NBC's introduction of the local content rules has in no way deterred Nigerian endogenous broadcasters' tendency of heavily depending on international contents. As they put it, "close to two decades after the establishment of the NBC, the Nigerian TV has not moved substantially away from the feature of programmes and news items whose origin and content is basically foreign" (Omoera and Ibagere, 2010).

Furthermore, the rareness of NBC's sanctions meted on Nigerian broadcasters for violation of the local content regulation does not automatically exonerate the Nigerian version of media indigenisation from its multiple irregularities. Indeed, the local content policy appears faulty from its designers' conception of the term "Nigeria content" and its failure to clearly define the concept of "Nigerianess" in its provisions bordering specifically on local content quota. These will be discussed indetail in the subsequent sections of this discourse

\subsection{Questionable Conceptualisation of Local Content}

It must be underlined from the outset that the concept of local content has mostly been elusive and complex. Most countries have mainly viewed local programs as those produced by nationals, which involve local talents (that is national talents), are designed for nationals and which are in line with national interests (Koblowe and Madu, 2012; Batharjee and Mendel, 2001). In tandem with this, the Broadcasting Services (Australian Content) Standard (1999), for instance, defines local content as any form of programming which is produced under the creative control of nationals of the country. Going by this definition, the document construes "Australian content" as any media program produced under the following conditions:

a. the producer of the program is, or the producers of the program are, Australian...; and

b. either: (i) the director of the program is, or the directors of the program are, Australian; or (ii) the writer of the program is or the writers of the program are, Australian; and

c. at least $50 \%$ of the leading actors, including voice actors, or on-screen presenters appearing in the program are Australian; and

d. in the case of a drama program - at least $75 \%$ of the major supporting cast appearing in the program are Australians; and

e. [ ...] the program is produced and post-produced in Australia...; and

f. in the case of an animated program - the program satisfies at least 3 of the following requirements: (i) the production designer is Australian; (ii) the character designer is Australian; (iii) the supervising layout artist is Australian; (iv) the supervising storyboard artist is Australian; (v) the key background artist is Australian.

The Nigerian Broadcasting Code has visibly followed this bandwagon in its way of defining local contents. In effect, the Code construes local content as any media production which adheres to the following principles:

a. [it is] made by authors, producers and workers who are Nigerians or residing in Nigeria; or,

b. produced under the creative control of Nigerians; or c. the production is supervised and controlled by a producer established in Nigeria; or,

d. the contribution in a co-production is not controlled by a producer based outside Nigeria; or

e. the production originating from any other country is made exclusively by Nigerians or in co-production with non-Nigerians established in that country.

From the definitional illuminations provided above, one clearly sees that the Nigerian Broadcasting Code basically focuses on the nationality of media producers and talents involved as well as on the country in which the production is done. Very little or no serious attention is given to indigenous languages as a key feature of indigenous program. Also, very little attention is given to the imperative of encouraging an original or purely Nigerian production style. These two major lacunas have engendered a situation wherein indigenous programs are marginalised or worse, local media producers and presenters struggle to package their productions glaringly according to Western production paradigms. A very clear - but often neglected evidence of this assumption is the fact that, more than often, Nigerian media presenters and journalists have struggled to use - or rather mimic - European and American accents during presentation of their programs, thereby sidelining Nigerian spoken English in a technical/subtle way. Such Westernised Nigerian journalists and media presenters have often "Americanised" the pronunciation of indigenous names, sometimes distorting them. In other cases, such local media producers have struggled to deliver their programs by mimicking their American or Western "idols". This scenario gives credence to the thesis stipulating that although some locally made programs may be Nigerian in terms of intended contents and talents involved in the production, the accent and production paradigms used in delivering them (the programs) qualify them as Western. Nigerian Television Authority (NTA) producer Henshaw decries this reality as he contends that:

There are numerous Nigeria-based radio and TV stations which are staffed with presenters who are fond of Americanizing the English language they use on air. While on air, such media personnel speak Americana or simply Americanized native names as if they were born in the West or as if they have not even grown up in this part of the world - that is Nigeria [...] 
They don't speak English language [with a Nigerian accent]. Though some of them have interesting contents [to offer] one is left to wander if their productions qualify as local content (Endong, 2014).

The way peoples of African descent pronounce words of the European languages as well as traditional African words is today arguably considered part of their identity (Bobda, 2000). This is in line with McWhorter's (2014) contention that "the way people talk expresses their identity". By implication, it is plausible to argue that, with no intent to be apologetic of mispronunciations of English words, the Nigerian way of pronouncing English constitutes part of Nigerianess. Therefore, reading the news or presenting a TV or radio program in Nigerian spoken English should arguably be viewed by Africans as a way of affirming their identity. It is probably in line with this understanding that well established global broadcasters such as the British Broadcasting Corporation(BBC), Aljazeera and even CNN tend to "tolerate" and integrate into their programming, news reports filed by African correspondents or staff-men in a type of English spoken with oriental or African accent. Programs such as BBC's Network Africa are good cases in point. Sharing corollaries, Steffensen (2012) opines that:

Language discrimination is recognised by the $\mathrm{BBC}$ as a problem in relation to its domestic audience and the Corporation actively attempts to become more inclusive and representative of British society by broadcasting nonstandard accents. On the other hand, when representing foreign, and especially post-colonial and non-Western languages and cultures, accent is used to define the boundary between the native English-speaking community and its outside. Accents are used to represent and translate the outside in stereotyping ways that tend towards racialisation and towards actors using generic "Southern African" and "East Asian" accents that bear little resemblance to the actual phonological profile of native speakers.

The lesson derivable from BBC's Network Africa in particular is that, even with a Nigerianised spoken English, good indigenous programs can be produced and Nigerianess can be advertised or promoted through the way the English language is used on air or in packaging $\mathrm{TV}$ or radio programs. Therefore, the Nigerian Broadcasting Commission should explore the linguistic dimension of local production.

A problem similar to the linguistic westernisation of socalled local productions is Nigerian producers' frequent adoption of Western styles of production, sometimes by adhering to cultural snobbism or social conformism. This can vividly be illustrated by the fact that much of the pop videos broadcast in TV musical programs on Nigerian celebrate various concepts that will mostly be identified as Western or at least exocentric. For instance, the pop videos of most Nigerian celebrities and superstars enact scenes very much similar to American artistes: singers, dancers and actors within these videos are most often dressed in a Western way and made to mimic gansta and AfroAmerican lifestyle or fashion. Going from this observation, one may pertinently argue that some of the musical programs authored by Nigerian producers and depicting Nigerians may not, by their content, be purely local. Many of them may, by default, be described as hybrid but with a dominant foreign (or Western) content. Former Managing Director of the Cross River Broadcasting Corporation (CRBC), Liwhu Betiang shares corollaries as he posits that:

The concept [of indigenization] is problematic. How do you define indigenisation? A programme may be local but with foreign form. It may be local with foreign content. It may equally be said to be local; but when you critically look at it, the idea driving its conception is not local, but emanates from elsewhere, for instance the famous reality show Big Brother Nigeria is clearly inspired by Big Brother UK [...] In such a situation of ambiguity, how do you define indigenisation? I strongly think that the concept is highly problematic. (Endong, 2015)

As noted by Betiang above and many other Nigerian media critics, there are still many blatant ambiguity and unvoiced issues in Nigeria's indigenisation policy and local content regulations. By failing to deal with this ambiguity and other silent issues, Nigeria's media local content policy - which is otherwise loaded with a fair philosophy - remains difficult to implement effectively. In the absence of a clear definition of its principles, the policy may simply be unfeasible.

\subsection{The Problematic 100\% Local Content}

The fact that the Nigerian Broadcasting Code institutes a 100 percent local content could be lauded in the country's conservative quarters; however, it must be underscored that the quota appears unrealistic, nonpragmatic and thus highly problematic to many Nigerian media producers. Indeed, it is highly problematic in a media environment where vital issues such as homegrown media technologies, investment in innovative programs, specialized programming with indigenized character continue to be a myth rather than a reality. The policy is also more of an ideal in a Nigeria where competition with (foreign) international broadcasters has intensified over the years with the help of the Internet, satellite and cable transmission. The best the Nigerian Broadcasting Commission has done so far in support of its local content regulation has been to create a National Content Development Fund in a bid to facilitate local content creation in the country (Kawu, 2018). However, the fruits of this initiative is yet to be palpable in the country's broadcasting sectors since local program creation continues to be exorbitantly high for both government owned and private broadcaster. This has been one of the factors responsible for local media's continuous and heavy dependence on foreign media contents. 
Besides the above mentioned issue, the progressive westernisation of audiences has motivated most Nigerian producers to preferably shape their productions according to Western standards, visibly to appeal to audiences' penchant, and possibly attract advertising revenues, and ultimately stay afloat. Nigeria Television Authority (NTA) producer Evelyn Nkanu underscores this situation when she contends that: Nigerian media producers and owners are so engrossed in western programs because the majority of audiences are likely to prefer what is western. Foreign content or local media programs fashioned according to western cultural values are strategies to capture the largest possible number of audiences and attract advertisers [...] You hardly see a media program aired in Nigerian radio or television which is totally indigenous [...] All because they are trying to satisfy an audience which has intensively been westernized. The so praised and recommended indigenization policy is not respected [...] I don't think the Nigerian media have been doing their best. They are not maximizing their potentials as far as encouraging the indigenization of media content is concerned. (cited in Endong, 2014)

Most conservative media critics are likely to interpret this capitalist and apparently "snobbish" tendency by Nigerian producers as a lack of cultural pride. However, logic has always warranted TV and radio broadcasters to go for models of programming that will attract audiences (who, as we know, are king in the market place of ideas). Preference for a model that attracts audiences allows media houses to stay afloat. As surmised by Dominick (2011), "In the mass audience stage, the potential audience consists of the entire population, with all segments of the society likely to be presented. Media content is designed to appeal to what has been called the 'least common denominator' in the audience" (p.483). The least common denominator in the Nigerian context is unfortunately Western media content. Pragmatic media producers are thus highly tempted to be conscious of this least common denominator which, by many indications, is "culturally problematic". The least common denominator in Nigeria is just westernised.

\section{CONCLUSION}

Cultural protectionism aided by media regulation remains a noble philosophy especially in the face of a Western cultural imperialism brought about by the globalisation current. However, the homogenisation and standardisation effects of globalisation have made it extremely difficult, if not herculean, to perfectly protect local cultures in Black Africa. This cultural globalisation has made it extremely difficult for local content policies to survive and to effectively be implemented in a bid to protect local cultures and industries in the media sectors of most Third World countries, Nigeria being included. In some countries, the local content regulation has either been a mirage, a myth or just a dead letter. In the Nigerian context in particular, it can be observed that this policy has faced many challenges, some of which are born by the continuous westernisation of Nigerian audiences and media producers, and others by the poorly articulated indigenisation policies adopted by the country. The media producers and presenters and secondary sources consulted in the context of this study have mostly censured the indigenisation policy as conceived by the Nigerian government. Although most of them acclaim the idea of introducing a local content regulation to ensure cultural protectionism in the Nigerian media sphere, they argue that government has, for the moment, failed to provide all the accompanying measures to secure the success of such a policy. The policy, as conceived by Nigeria, does not provide a comprehensive and acceptable definition of local program and Nigerianess. Also, the policy's insistence on a 70-100 percent is really utopian. It overlooks the fact that Nigerian audiences have progressively become westernised, and that logic will want media producers to pragmatically go for western or westernised media programs, so as to stay afloat. Following this logic, many Nigerian producers have been unpunished and unrepentantly continued to borrow media production paradigms from the West, while most Nigerian broadcasters have unabatedly continued to dominantly depend on foreign contents to stay afloat.

Etik Beyan: Bu çalışmada "Etik Kurul” izini alınmasını gerektiren bir yöntem kullanılmamıştır

Yazar Katkı Beyanı:1. Yazarın katkı oranı \%100'dür.

Ethics Statement: In this study, no method requiring the permission of the "Ethics Committee" was used. Author Contributions Statement: 1st author's contribution rate $100 \%$ 


\section{REFERENCES}

Aliagan, A. R. (2017). Kawu: Changing the narrative in Nigeria's broadcasting industry. Time http://timenigeria.com/kawu-changing-the-narrative-in-nigerians- broadcasting-industry/ (Accessed 9, 2018).

NigeriaMagazine,

Bobda, A.S. (2000). The uniqueness of Ghanaian English pronunciation in West Africa. Studies in the Linguistic Science. 30(2), 185-198.

Centre for International Governance Innovation. (2014). The internationalisation of indigenous UNDRIP in Canadian context. Special report. Waterloo: CIGI.

r i g h t s :

Effiom, V. E. (2005). Electronic media management in a developing democracy. Calabar: Balynhen Nigeria Limited.

Ekpang, E. J. (2008). Globalization and cultural imperialism: The Nigerian experience. West African Association for Commonwealth Literature and Language Studies 2(2), 1-17.

Endong F. P. (2014). Westernisation of audiences as a threat to the indigenisation of media broadcast in Nigeria. In JMC: Journal of Media and Communication Studies 6(8), 121-129.

Endong, F. P. C. (2015). Indigenisation of media in Nigerian and cultural globalisation: Mutual bedfellows or implacable foes? Journal of Globalization Studies 6(2), 106-118.

Endong, F. P. C. (2018). Culture and heritage preservation in an era of globalization and modernism. A comparative study of China and Nigeria. In Handbook of research on heritage management and preservation, ed. Patrick Ngulube, pp. 320-339. Hersey: IGI Global.

Forbes. (2017). Globalisation. https://www.forbes.com/sites/quora/2017/08/28/is-globalization-creating-a-singleworld-culture/\#c0a417a3bd36 (Accessed 7 April, 2018).

Grawhall, N. (2006). MDGs, globalisation and indigenous people in Africa. Indigenous Affairs 1(6): 6-13.

Huntington, S. (1993). The clash of civilizations. Foreign Affairs. 72 (3), 22-49.

Koblowe, O. \& Madu, O. (2012). Programming content of Nigerian broadcast media: Towards an indigenizing paradigm. in Estudos em comunicacao 1(8), 75-91.

Leornard, C. (2016). Local content quotas on TV are global - but they just don't work everywhere. The Conversation https://theconversation.com/local-content-quotas-on-tv-are-global-but-they-just-dont-work-everywhere-60656 (Accessed May 9th, 2021).

McWhorter, J. (2014). The "ax" versus the "ask" question. Los Angeles Times. http://articles.latimes.com/2014/jan/19/ opinion/la-oe-mcwhorter-black-speech-ax-20140119. (Accessed May 3rd, 2021).

Nigerian Broadcasting Commission. (2016). The Nigerian Broadcasting Code (6th edition), Abuja: Nigerian Broadcasting Commission.

Omoera, O.S. \& Ibagere, E. (2010). Revisiting media imperialism: A review of Nigerian television experience. The International Journal of Science and Review 5: 1-18.

Revise Sociology (2015). What is cultural globalisation. Revise Sociology. https://revisesociology.com/2017/05/25/ cultural-globalization-definition-examples/ (Accessed 7 April, 2018).

Salawu, A. (2004). The Yoruba and their language newspaper: Origin, nature, problems and prospect. Studies of Tribes and Tribals. 2(2), 79-92.

Salawu, A. (2006). Paradox of a milieu: Communication in African indigenous languages in the age of globalisation. In Indigenous language media in Africa, ed. Salawu A., pp.1-20. Lagos: Centre for Black and African Arts and Civilisation (CBAAC). 
Samalavicius, A. (2005). Culture and globalization. Eurozine. Retrieved April 9th, 2018, from eurozine.com/national-identity-culture-and-globalisation/

https://www.

Steffensen, N. K. (2012). BBC with an Accent: “African” and “Asian” Accents. Meta, LVII(2), 510-527.

Suryadinata, L. (2011). Migration, indigenisation and interaction. Chinese overseas and globalisation. Singapore : World Scientific Publication Co.

Thinus, F. (2016). SABC set to bulldoze SABC3 schedule. Channel 24, from https://www.channel24.co.za/TV/News/ sabc-set-to-bulldoze-sabc3-schedule- 20160601 (Accessed May 9, 2018).

Van der Puye, F. (2008). Media and the preservation of culture in Africa. Cultural Survival Quarterly Magazine, 22(2), 32-49. https://www.culturalsurvival.org/publications/cultural-survival-quarterly/media-and-preservation-culture-africa (Accessed May 11, 2018).

Watson, J. L. (2016). Cultural globalisation. Encyclopedia Bitannica. https://www.britannica.com/science/culturalglobalization (Accessed September 8, 2016). 